\title{
The total cellularity of the bone marrow in $\operatorname{man}^{1}$
}

\author{
W. J. HARRISON
}

From the Department of Haematology, Westminster Hospital, London ${ }^{2}$

SYNOPSIS The $\mathrm{Fe}^{59}$ method of Suit (1957) has been used to estimate total bone marrow cellularity $\overrightarrow{\vec{\omega}}$ in 10 haematologically normal patients. A mean figure of $10.4 \times 10^{9}$ nucleated cells $/ \mathrm{kg}$. body weight $\stackrel{\circ}{\circ}$ was obtained. Simultaneous estimates from marrow obtained by rib excision produced a mean? value of $11 \cdot 1 \times 10^{9}$ nucleated cells $/ \mathrm{kg}$.

Previous work by this and other methods is reviewed. While some results agree well with those of the present work, one is higher by $50 \%$ and another by $300 \%$. Corrections are suggested which $\tilde{~} \mathrm{~J}$ reduce these figures and bring all published results within a small range.

Reasonably accurate determinations of total marrow cellularity in disease will not be possible until more is known of marrow $\mathrm{Fe}^{59}$ uptake in abnormal states.

The quantitative study of human bone marrow has attracted comparatively little attention largely because of the technical difficulties involved, but since the introduction of marrow replacement therapy it has achieved some practical importance. The direct measurement of the haemopoietic marrow cavities and their cellularity per unit volume has been carried out in experimental animals. Osgood (1954) and Patt (1957) calculated human total marrow cellularity from data on the kinetics of red cell production, and its direct measurement in living subjects was first carried out by Suit (1957) who used radioactive iron as a marrow label.

Following an intravenous dose of a radioiron salt in a normal subject the plasma radioactivity falls rapidly and is largely taken up by red cell precursors at all stages from the basophilic normoblast to the late reticulocyte. The radioactivity reappears in the blood during the next few days in the red cells and the activity in the total red cell mass rises to a maximum of 70 to $90 \%$ in seven to 10 days. The time of minimum whole blood activity occurs rather less than 24 hours after the injection.

Suit's basic assumption was that all the radioiron in red cells eight days after an injection is derived from that present in the marrow at 24 hours, apart from a small fraction of the dose which is taken up directly by circulating reticulocytes. The

Received for publication 22 December 1961.

'Based on a paper read at a meeting of the Association of Clinical Pathologists on 22 September 1961.

${ }^{2}$ Present address: Department of Morbid Anatomy, Westminster Hospital Medical School, London, S.W.1. total marrow radioactivity at 24 hours is thus given by the red cell radioiron utilization at eight days : minus the utilization at $\mathbf{2 4}$ hours. Then, as marrow radioactivity is proportional to the number of red cell precursors, the ratio of cellularity to radioactivity is the same in the total body marrow as in a marrow sample:-

Cellularity of marrow sample

Radioactivity of marrow sample

Cellularity of total marrow

Radioactivity of total marrow

The marrow sample is obtained at 24 hours and total marrow cellularity can then be obtained from the above equation.

The central problem in applying this technique is 0 in estimating the proportion of the injected radioiron $₹$ dose in the total marrow at the time of sampling. 옥 By assuming that, apart from direct reticulocyte $D$ radioiron uptake, red cell radioactivity at eight days is all derived from the initial marrow uptake, total N cellularity is probably overestimated by between $10^{\circ}$ and $20 \%$, because some radioiron passes directly ${ }_{0}$ from the plasma to iron stores, and is only later used $\mathbb{\omega}_{\mathrm{N}}$ by the marrow for haemoglobin synthesis, probablyo after the fifth day (Bothwell, Callender, Mallett, ande Witts, 1956). Donohue, Gabrio, and Finch (1958) measured the carcass localization of radioiron? directly by sacrificing animals at the time of minimum blood activity, and, extrapolating the results to man, suggested that $66 \%$ of the injected radioiron is in the marrow after 14 to 18 hours. This figure for total marrow radioactivity, although obtained $\frac{O}{O}$ indirectly, seems the best available, and has been 
used in the present study for two reasons: first, it confirms that the eight-day utilization is a slight overestimate; and secondly, in all the patients studied the steady state was disturbed soon after marrow sampling either by the blood loss and replacement associated with thoracotomy, or by chemotherapy for malignant disease.

The purposes of the present study were threefold: first, by performing simultaneous estimations using rib marrow removed surgically and aspirated marrow in the same patient, to see whether dilution of aspirated marrow with blood introduced significant errors; secondly, to discover whether the normal range of results was small enough for the aspiration of $\mathrm{Fe}^{59}$-tagged marrow to provide useful individual results in clinical haematology; and, thirdly, to investigate marrow cellularity in abnormal haemopoiesis.

\section{MATERIALS AND METHODS}

Ten adult patients were selected as normal for the purposes of this investigation. They were undergoing thoracotomy for mitral stenosis (3), bronchiectasis (3), bronchial carcinoma (3), and in one case, coarctation of the aorta. All were apyrexial and had normal blood counts. None had evidence of cardiac failure, blood loss, dissemination of malignancy, or any other disturbance which might seriously affect haemopoiesis. Marrow was aspirated from the posterior iliac spine when the patient was anaesthetized and on the operating table awaiting thoracotomy. The rib was removed within 20 minutes of taking the aspirated sample.

Seven patients with malignant melanoma in various stages of dissemination were also studied. Mild sedation was prescribed for two anxious patients, although the aspiration of comparatively large volumes of marrow was well tolerated.

The following procedure was adopted for marrow aspiration in order to minimize dilution with blood. In conscious patients a wide area of periosteum over the posterior superior iliac spine and adjacent part of the crest was infiltrated with $1 \%$ procaine and hyalase (1,500 units). Marrow was aspirated with a Waterfield needle (iliac crest pattern) from several closely adjacent sites through the same skin puncture. At each site aspiration was performed at two depths and in this way no more than $2 \mathrm{ml}$. was obtained in each position, a highly cellular sample with a total volume of 12 to $15 \mathrm{ml}$. being obtained (Table III). When the cellularity is low the difference between the $\mathrm{Fe}^{59}$ activity of equal volumes of aspirated marrow and venous blood taken simultaneously is correspondingly low and this can be a major source of error in the final result.

Marrow was obtained from ribs and sieved as described by Pegg and Kemp (1960). The ribs were cut into centimetre lengths with rib shears, splitting the pieces and exposing the contained marrow. These rib fragments were placed in a siliconed $250 \mathrm{ml}$. conical flask containing $30 \mathrm{ml}$. heparinized tissue culture fluid (T.C.199 Glaxo, containing 50 units $/ \mathrm{ml}$. of heparin), and agitated mechanically for three to five minutes. Light centrifugation left the fat floating on the surface. This was removed since it was acellular and contained negligible $\mathrm{Fe}^{59}$ activity, while its presence made cell counting more difficult. The deposit was resuspended and pressure filtered through wire meshes of pore size 380 and $80 \mu$. Cell counts and radioactivity measurements were made on this suspension, and reticulocyte preparations and films for myelograms were made from the deposit obtained on further centrifugation. Conventional, acidified white cell diluents could not be employed for cell counting as they produced massive clumping of cells, presumably due to precipitation of components of damaged cells. This did not occur with $0.1 \%$ aqueous brilliant cresyl blue which was found to be satisfactory.

Aliquots, each of $10 \mathrm{ml}$., of the marrow cell suspension were used for radioactivity measurements except in two cases where $5 \mathrm{ml}$. was used. In order to estimate the amount of radioactivity released from cells during manipulations, measurements were also made on separate aliquots of the cell-free supernatant and the centrifuged deposit.

$\mathrm{Fe}^{59}$ as ferric citrate in isotonic saline at $p \mathrm{H} 7.0$ was injected 16 hours before the expected time of marrow sampling. Patients with malignant disease received 20 to $30 \mu \mathrm{c}$ while others received $10 \mu \mathrm{c}$. The lower dose gave adequate counting rates. In the first three cases plasma $\mathrm{Fe}^{59}$ half-clearance time was measured and found to be normal $(86,106$, and 98 minutes). This was considered evidence of adequate iron binding in vivo and unbound $\mathrm{Fe}^{59}$ was injected in all subsequent cases. Bothwell, Hurtado, Donohue, and Finch (1957) in two normal subjects found that clearance was virtually the same whether or not the $\mathrm{Fe}^{59}$ was incubated with plasma before injection.

SAMPle Calculation (Patient 5) All $\mathrm{Fe}^{59}$ estimations were on $5 \mathrm{ml}$. samples.

Patient's weight $=40.9 \mathrm{~kg}$.

Vol. of $\mathrm{Fe}^{59}$ injection $=20 \mathrm{ml}$.

Activity of $1: 20$ dilution $=3,335$ c.p.m. (counts/min.).

SAMPLES TAKEN AT 16 HOURS
1 Blood
$\mathrm{Hb}=14 \cdot 2 \mathrm{~g} . / 100 \mathrm{ml}$.
W.B.C. $=7,200 / \mathrm{c} . \mathrm{mm}$. $\mathrm{Fe}^{59}$ activity $=2 \cdot 63$ c.p.m.
2 Aspirated marrow $\mathrm{Hb}=14.0 \mathrm{~g} . / 100 \mathrm{ml}$. T.N.C. $=19,000 /$ c.mm. $\mathrm{Fe}^{59}$ activity $=32.0$ c.p.m.
3 Rib suspension T.N.C. $=37,400 /$ c.mm. $\mathrm{Fe}^{59}$ activity $=76 \cdot 6$ c.p.m.

Total marrow $\mathrm{Fe}^{59}$ activity at 16 hours $=0.66 \times$ injected counts $=0.66 \times 20 \times \frac{3,335}{5} \times 20=1.76 \times 10^{5}$ c.p.m.

Calculation on Aspirate

Marrow cells in aspirate $=(19,000-7,200) \times 5 \times 10^{3}$ $=5.90 \times 10^{7}$

$\mathrm{Fe}^{59}$ activity of aspirate due to marrow

$$
\begin{aligned}
& =32 \cdot 0-\left(\frac{14 \cdot 0}{14 \cdot 2} \times 2.63\right) \\
& =29 \cdot 4 \text { c.p.m. }
\end{aligned}
$$


Marrow cellularity $/ \mathbf{k g}$. =

total marrow $\mathrm{Fe}^{59}$ activity $\times$ sample cellularity

$$
\text { sample } \mathrm{Fe}^{59} \text { activity } \times \text { body weight }
$$

$$
\begin{aligned}
& =\frac{1.76 \times 10^{5} \times 5.90 \times 10^{7}}{29.4 \times 40.9} \\
& =8.6 \times 10^{9}
\end{aligned}
$$

Calculation on rib marrow

$$
\begin{aligned}
\text { Marrow cellularity } / \mathrm{kg} . & =\frac{1.76 \times 10^{5} \times 37,400 \times 5 \times 10^{3}}{76.6 \times 40.9} \\
& =10.5 \times 10^{9}
\end{aligned}
$$

\section{RESULTS}

The individual results obtained by the two methods used in the 10 'normal' cases are given in Table I. The erythroid marrow (nucleated red cells) may be calculated from these figures using the percentages of nucleated red cells in rib marrow and the corrected percentages of nucleated red cells in aspirated marrow given in Table II.

TABLE I

NUCLEATED MARROW CELLS/ $\mathrm{kg}$. BODY WEIGHT $\times 10^{-9}$ IN 'NORMAL' PATIENTS

Patient

Method

\begin{tabular}{lcc} 
& Rib Marrow & Aspirated Marrow \\
\hline 1 & $8 \cdot 2$ & $4 \cdot 7$ \\
2 & $9 \cdot 2$ & $16 \cdot 7$ \\
3 & $4 \cdot 1$ & $10 \cdot 9$ \\
4 & $23 \cdot 5$ & $9 \cdot 6$ \\
5 & $10 \cdot 5$ & $8 \cdot 6$ \\
6 & $7 \cdot 3$ & $12 \cdot 9$ \\
7 & $13 \cdot 0$ & $11 \cdot 2$ \\
8 & $11 \cdot 0$ & $12 \cdot 5$ \\
9 & $9 \cdot 9$ & $6 \cdot 8$ \\
10 & $14 \cdot 4$ & $10 \cdot 1$ \\
Mean & $11 \cdot 11$ & $10 \cdot 40$ \\
Standard deviation & $5 \cdot 25$ & $3 \cdot 36$
\end{tabular}

The difference between the means is not statistically significant.

An explanation of the 'corrected' nucleated red cell percentage in aspirated marrow is necessary. Rib marrow contains insufficient blood to contribute appreciably to the nucleated cell count. The estimation of total marrow cellularity is therefore straightforward and erythroid cellularity is obtained directly from the myelogram, averaging $28.4 \%$ of the total. However, with aspirated marrow, only erythroid cellularity can be determined directly since the peripheral blood white cell count (W.B.C.) makes an important contribution to the total nucleated cell count (T.N.C.) in the marrow sample. In Table II, nucleated red cells are expressed as a percentage of the T.N.C. ('observed NR\%') and as a percentage of (T.N.C.-W.B.C.) ('corrected NR\%'). It will be seen that the corrected nucleated red cell percentage approaches that of rib marrow in each

\begin{tabular}{|c|c|c|c|c|c|}
\hline Case & T.N.C. & $\begin{array}{l}\text { T.N.C.- } \\
W . B . C .\end{array}$ & $\begin{array}{l}\text { Observed } \\
\text { N.R. }(\%)\end{array}$ & $\begin{array}{l}\text { Corrected } \\
\text { N.R. (\%) }\end{array}$ & $\begin{array}{l}\text { Rib } \\
\text { N.R. ( } \% \text { ) }\end{array}$ \\
\hline 1 & 18,000 & 12,000 & $16 \cdot 2$ & $24 \cdot 3$ & $21 \cdot 4$ \\
\hline 2 & 48,200 & 41,600 & $23 \cdot 5$ & $27 \cdot 2$ & $38 \cdot 6$ \\
\hline 3 & 22,100 & 14,200 & $16 \cdot 1$ & $25 \cdot 0$ & $27 \cdot 0$ \\
\hline 4 & 56,500 & 49,500 & 18.0 & $20 \cdot 6$ & $27 \cdot 0$ \\
\hline 5 & 19,000 & 11,800 & $14 \cdot 6$ & $23 \cdot 5$ & $28 \cdot 2$ \\
\hline 6 & 66,000 & 58,800 & $21 \cdot 7$ & $24 \cdot 4$ & $28 \cdot 5$ \\
\hline 7 & 72,400 & 63,300 & $26 \cdot 6$ & $30 \cdot 5$ & $29 \cdot 7$ \\
\hline 8 & 95,600 & 87,600 & $24 \cdot 3$ & $26 \cdot 5$ & $23 \cdot 2$ \\
\hline 9 & 57,600 & 50,900 & $22 \cdot 1$ & $25 \cdot 0$ & $28 \cdot 3$ \\
\hline 10 & 37,400 & 28,300 & $24 \cdot 3$ & $32 \cdot 1$ & $32 \cdot 1$ \\
\hline \multicolumn{4}{|c|}{ Average } & $25 \cdot 9$ & $28 \cdot 4$ \\
\hline
\end{tabular}
case, although the average is slightly lower $(25.9 \%$
TABLE II

THE EFFECT OF BLOOD ON CELL COUNTS ON ASPIRATED MARROW

as against $28.4 \%$ ). This suggests that the true marrow cell count in an aspirated sample is given quite $\mathrm{N}$ simply by subtracting W.B.C. from T.N.C. and that it provides a method for obtaining the true myeloid-erythroid ratio and the true myelogram. Pontoni (1936) excluded all mature polymorphonuclears from the myelogram but this ignores the fact that marrow removed surgically contains an

\begin{tabular}{|c|c|}
\hline Cell Type & Percentage \\
\hline Reticulum cells & 0.7 \\
\hline Myeloblasts & $1 \cdot 6$ \\
\hline Promyelocytes & $1 \cdot 5$ \\
\hline Myelocytes neutrophil & $12 \cdot 3$ \\
\hline eosinophil & 1.9 \\
\hline basophil & $0 \cdot 1$ \\
\hline Metamyelocytes neutrophil & $26 \cdot 9$ \\
\hline eosinophil & $3 \cdot 2$ \\
\hline basophil & 0.0 \\
\hline Polymorphonuclears neutrophil & $12 \cdot 9$ \\
\hline eosinophil & $2 \cdot 4$ \\
\hline basophil & $0 \cdot 1$ \\
\hline Lymphocytes & 3.4 \\
\hline Monocytes & $\mathbf{0} \cdot \mathbf{3}$ \\
\hline Plasma cells & 0.7 \\
\hline Pronormoblasts & 0.47 \\
\hline Basophilic normoblasts & 3.5 \\
\hline Polychromatic normoblasts & $24 \cdot 3\} 28 \cdot 4$ \\
\hline Orthochromatic normoblasts & 0.2 \\
\hline Unidentified cells & $1 \cdot 3$ \\
\hline Smudged cells & $2 \cdot 3$ \\
\hline & $100 \cdot 0$ \\
\hline
\end{tabular}
appreciable number of these cells (Table III).

TABLE III

MEAN OF MYELOGRAMS ON 10 SUSPENSIONS OF RIB MARROW ${ }^{1}$

Reticulocytes/1,000 normoblasts $\quad 989$

${ }^{1}$ One thousand nucleated cells were counted in each case

Table IV shows the results in seven cases of malignant melanoma and summarizes the salient clinical and haematological features in each case.

\section{DISCUSSION}

Techniques applicable to the estimation of marrow cellularity in man have recently been reviewed by 
TABLE IV

NUCLEATED MARROW CELLS $/ \mathrm{kg}$. BODY WEIGHT $\times 10^{-9}$ (ASPIRATED MARROW METHOD) IN MALIGNANT MELANOMA

\begin{tabular}{cclll} 
Patient & Cellularity & $\begin{array}{l}\text { Blood } \\
\text { Count }\end{array}$ & $\begin{array}{l}\text { General } \\
\text { Condition }\end{array}$ & $\begin{array}{l}\text { Recent } \\
\text { X-Rays or } \\
\text { Chemotherapy }\end{array}$ \\
\hline 11 & $10 \cdot 0$ & Normal & Ascites & Yes \\
12 & $16 \cdot 2$ & Normal & Good & No \\
13 & $7 \cdot 0$ & Normal & Good & No \\
14 & $7 \cdot 2$ & Normal & Ascites & No \\
15 & $8 \cdot 3$ & Hb 60\% & Poor & Yes \\
16 & $8 \cdot 8$ & Hb $58 \%$ & Poor & Yes \\
$17^{1}$ & $28 \cdot 3$ & Normal & Good & Yes
\end{tabular}

${ }^{1}$ Patient 17 completed a course of phenylalanine mustard only three days before this test was performed.

Pegg (1962). They fall into three groups which will be considered in turn.

1 ANATOMICAL METHODS In animals measurements have been made of the volume of the haemopoietic marrow cavities and of the cellularity per c.mm. (Kindred, 1942). Such work is very exacting and, unless the unit cellularity of each of the major sites of red marrow is determined separately, is subject to considerable errors.

Although the method has not been applied to man, Pegg (1962) has pointed out that data already available enable this to be done. Mechanik (1926) measured the marrow volume of the individual bones in cadavers and his results have been abstracted and summarized by Woodard and Holodny (1960). Using the number of nucleated cells obtainable from one rib and the graphs of Custer (1932) for the relative cellularity of ribs and vertebrae, total marrow cellularity is calculated as $8.1 \times 10^{9}$ nucleated cells per $\mathrm{kg}$.

2 ERYTHROKINETIC METHODS Osgood's calculation of the total number of marrow cells (Osgood, 1954) rested on five main assumptions:-

1 That the red cell production rate is derived from the blood volume and a red cell life span of 120 days; 2 , that the total time for differentiation from the last mitosis in the normoblast series until release from the marrow is 48 hours; this was derived from the timing of the reticulocyte response and the disappearance of megaloblasts following parenteral liver therapy, and from the rate of disappearance of normoblasts after irradiation; 3 , that one quarter of nucleated red cells contain nucleoli and are capable of mitosis; 4 , that the myeloid erythroid ratio is $3: 1$; and, finally, 5, that reticulocytes spend a negligible time in the marrow. The finding of Reiff, Nutter, Donohue, and Finch (1958) that the marrow reticulocytes are approximately equal in number to the normoblasts is confirmed in the present study (Table III) and cannot be reconciled with Osgood's last assumption. On the contrary, it seems probable that the reticulocyte stage occupies a proportion of the maturation time approximately equal to that of the normoblast.

The results obtained were $8.6 \times 10^{9}$ erythroid cells and $46 \times 10^{9}$ per $\mathrm{kg}$. for the total marrow. These figures are four times higher than the average by other methods, but a considerable reduction is effected by including the marrow reticulocyte stage, and a smaller reduction by assuming a myeloiderythroid ratio of $2: 1$ and a myelogram with $30 \%$ nucleated red cells. After recalculation the figures become $3.7 \times 10^{9}$ cells $/ \mathrm{kg}$. for erythroid marrow and $12.3 \times 10^{9}$ cells $/ \mathrm{kg}$. for the total marrow.

Patt (1957) used the same red cell production rate, the duration of mitosis (mitotic time), and the percentage of cells in mitosis at any one time, mitotic index (Japa, 1942). In this calculation the greatest potential source of error is the fairly wide range of published figures for mitotic time (Hoffman, 1953; Ris, 1955) but the fact that Patt's result accords so well with the others in Table $\mathrm{V}$ suggests that the assumed mitotic time of 45 minutes is reasonably accurate.

\section{TABLE V}

NUCLEATED MARROW CELLS/kg. BODY WEIGHT $\times 10^{-9}$ IN 'NORMAL' MAN

\begin{tabular}{llcc} 
Author & Method & $\begin{array}{c}\text { No. of } \\
\text { Cases }\end{array}$ & Result \\
\hline Pegg (1962) & Anatomical & & $8 \cdot 1$ \\
Osgood (1954) & Erythrokinetic & & $12 \cdot 3^{1} \quad(46 \cdot 0)^{2}$ \\
Patt (1957) & Erythrokinetic & & $13 \cdot 6$ \\
Suit (1957) & $\mathrm{Fe}^{59}$ (aspiration) & 6 & $7 \cdot 7^{3}$ \\
Donohue et al. (1958) & $\mathrm{Fe}^{59}$ (rib) & 7 & $12 \cdot 8^{1}(18 \cdot 0)^{2}$ \\
Present report & $\mathrm{Fe}^{59}$ (rib) & 10 & $11 \cdot 1$ \\
Present report & $\mathrm{Fe}^{59}$ (aspiration) & 10 & $10 \cdot 4$
\end{tabular}

${ }^{1}$ Figures obtained after the recalculations suggested in the text. ${ }^{2}$ Original figures.

${ }^{3}$ Not claimed as normal: probably an underestimate.

3 RADIOACTIVE IRON METHOD Suit (1957) estimated the whole body erythroid marrow in six cases using aspirated marrow samples and his results ranged from 6 to $24 \times 10^{10}$. The figure given in Table $\mathrm{V}$ $\left(7.7 \times 10^{9}\right.$ cells $/ \mathrm{kg}$. for total marrow $)$ is obtained by assuming that the body weights averaged $70 \mathrm{~kg}$. and that the erythroid marrow was $30 \%$ of the total marrow. Suit considered that, as his patients had malignant diseases '.. . which often result in progressive anaemia ...', his values were below normal.

In studies on seven patients undergoing thoracotomy for tuberculosis Donohue, Gabrio, and Finch (1958) obtained a mean value for total marrow cellularity of $18 \times 10^{9}$ cells/ $\mathbf{k g}$. Radioactivity was 
measured in the centrifuged deposit of an aliquot of the rib marrow suspension but they found that $29 \%$ of the radioactivity was in the cell-free supernatant and showed convincingly that most of it was contained in haemoglobin from damaged cells. A similar figure $(31 \%)$ was obtained in the present study. It is probable that this activity comes from the cytoplasm of cells whose nuclei are intact and therefore included in cell counts, and it is essential to measure the radioactivity of the whole suspension and not only the centrifuged deposit. When the figure of $18 \times 10^{9}$ cells $/ \mathrm{kg}$. is recalculated to allow for an average supernatant $\mathrm{Fe}^{59}$ activity of $29 \%$ the estimate is reduced to $12.8 \times 10^{9} \mathrm{cells} / \mathrm{kg}$. (Table V).

In the present study the close agreement between the averaged results for total cellularity using rib and aspirated marrow confirms that dilution of the latter by blood does not introduce appreciable errors, provided a simple allowance is made in proportion to the red cell counts or haemoglobin levels of the blood and marrow specimens. Individual differences between the duplicated estimates, most marked in the first four patients studied, must be due to technique. Suit (1957) discusses at some length possible errors due to the presence of younger reticulocytes with greater iron uptake in the aspirated marrow and concludes that this could cause an underestimate of $20 \%$ although a much smaller error was considered to be more probable. An analysis of the effects of these young reticulocytes suggests that the error would be less than $1 \%$ in practice. The reasons for this surprisingly small figure are best explained by considering the two basic equations :

Cellularity of whole marrow

Cellularity of marrow sample $=$

$\frac{\text { Radioactivity of whole marrow }}{\text { Radioactivity of marrow sample }} \ldots$. I

and

Radioactivity of marrow sample $=$ radioactivity of aspirate $-\frac{\text { radioactivity of blood } \times \text { R.B.C. of aspirate }}{\text { R.B.C. of blood }}$. II

It might appear that the presence of reticulocytes with a high $\mathrm{Fe}^{59}$ content would affect equation I, but in fact the ratio of marrow reticulocytes to nucleated red cells is the same in the whole marrow as in the aspirated sample, and the ratio of $\mathrm{Fe}^{59}$ activities due to nucleated cells plus reticulocytes is the same as that due to nucleated cells alone. On the other hand, there is an error due to reticulocytes in equation II; this is due to the fact that the blood red cell count includes blood reticulocytes whereas the marrow aspirate red cell count includes blood reticulocytes and marrow reticulocytes. However, this excess of reticulocytes forms an almost insignificant proportion of the total red cell count which in any case has a high inherent error. A sample calculation gave an underestimate of $0.2 \%$ for marrow cellularity.

It is important to know whether the wide range covered by the results in Table I reflects real physiological variations, or whether it is due, at least in part, to technical considerations. The latter is perhaps the more likely. Individual variations in marrow $\mathrm{Fe}^{59}$ क uptake could not be allowed for by estimating red $\vec{\circ}$ cell $\mathrm{Fe}^{59}$ utilization because of thoracotomy. However, even when this is done, Suit (1957) found a $\bar{\omega}$ fourfold difference between the highest and lowest results. Variation in body build and composition ? could account for a small part of the range and it $\overrightarrow{c r}$ would probably be better to express such results in $\omega$ relation to the ratio of the body weight to the cube $N$ of the height as suggested by Zilva and Nicholson (1960) for bromide space. Whatever the reason for $\frac{5}{I}$ the range of results, it is clear that individual results are of little value and that work must continue to be done upon groups of subjects whose haematological status is similar. It had been hoped that marrow $\vec{\mathscr{}}$ aspiration would provide a simple and reasonably $N$ accurate method for determining individual marrow cellularity. It is well known that there is a wide variation in the amount of leucocyte and platelet depression which follows anti-tumour chemotherapy and it has been suggested that this may often be due $\stackrel{\mathbb{Q}}{\mathbb{Q}}$ to a reduction in the total mass of bone marrow by $\overrightarrow{\vec{A}}$ metastases or previous radiotherapy. A simple method for predicting the response of these patients would be most valuable (Pegg, 1960).

The measure of agreement between the results obtained by such diverse methods (Table V) is? remarkable, especially in view of the uncertainty concerning some of the data used. The normal value for human marrow cellularity appears to be between $\delta$ 10 and $13 \times 10^{9}$ nucleated cells $/ \mathrm{kg}$. $\left(0.7-0.9 \times 10^{12} ₹\right.$ for a $70 \mathrm{~kg}$. man). On this basis the average yield of 을 nucleated marrow cells at multiple marrow puncture $\supset$ by the method of Pegg and Kemp (1960) is $1 \%$ of the whole marrow.

ABNORMAL MARROW CELLULARITY The estimation of total marrow cellularity in disease by the radio- $\omega$ iron method presents a difficult problem, mainly్ㅜ because of lack of information on the proportion of injected radioiron in the marrow at the time of minimum whole blood activity. Red cell radioiron? utilization could not be used to derive total marrow radioactivity unless 'ineffective erythropoiesis', ran-음 dom haemolysis, and blood loss could be excluded ${ }_{\mathcal{Q}}^{\mathbb{\Phi}}$

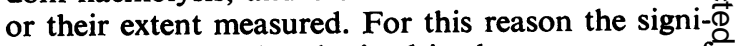
ficance of the results obtained in the seven cases of disseminated malignant melanoma, which are shown 
in Table IV, is uncertain. Where the general condition is described as 'good' the patient had demonstrable secondary deposits only subcutaneously or in one group of regional lymph nodes. The mean is $11.2 \times 10^{9}$ cells per $\mathrm{kg}$., virtually the same as in the normal cases. This is probably an overestimate since marrow radioiron uptake is likely to be depressed, and less than the assumed figure of $66 \%$ at the time of sampling. In this small group there is no correlation between the clinical and haematological state and marrow cellularity.

Experiments under controlled conditions would be possible if measurements of marrow cellularity by the $\mathrm{Fe}^{59}$ method were made on patients receiving irradiation to a major part of the haemopoietic marrow. The proportion being irradiated could be calculated from the data of Ellis (1961). This author has tabulated Mechanik's data (Mechanik, 1926) on the weight of marrow in individual bones and used the figures of Custer (1932) on the relative cellularity of ribs, sternum, and vertebrae to estimate the percentage of the whole red marrow in each bone. A further advantage of this type of study would be that, over the short period of the investigation, the remaining non-irradiated marrow would take up $\mathrm{Fe}^{59}$ normally.

I am most grateful to Dr. J. G. Humble for his interest and encouragement, to Dr. D. E. Pegg, who drew my attention to this subject, for many valuable discussions, and to the physicians and surgeons of Westminster Hospital who allowed me to study their patients; to Sir Stanford Cade, Dr. W. E. Lloyd, Dr. K. A. Newton, Dr. C. J. Gavey, and, in particular, Mr. C. E. Drew who performed the thoracotomies.

\section{REFERENCES}

Bothwell, T. H., Callender, S. T., Mallett, B., and Witts, L. J. (1956). Brit. J. Haemat., $2,1$.

- , Hurtado, A. V., Donohue, D. M., and Finch, C. A. (1957). Blood, 12, 409.

Custer, R. P. (1932). J. Lab. clin. Med., 17, 951.

Donohue, D. M., Gabrio, B. W., and Finch, C. A. (1958). J. clin. Invest., 37, 1564.

Ellis, R. E. (1961). Phys. in med. Biol., 5, 255.

Hoffman, J. G. (1953). The Size and Growth of Tissue Cells. Thomas, Springfield, Illinois.

Japa, J. (1942). Brit. J. exp. Path., 23, 272.

Kindred, J. E. (1942). Amer. J. Anat., 71, 207.

Mechanik, N. (1926). Z. Anat. Entwickl.-Gesch., 79, 58.

Osgood, E. E. (1954). Blood, 9, 1141.

Patt, H. M. (1957). Ibid., 12, 777.

Pegg, D. E. (1960). British Empire Cancer Campaign: 38th Annual Report. Part II: The Scientific Report, p. 338.

- (1962). In press.

_ and Kemp, N. H. (1960). Lancet, 2, 1426.

Pontoni, L. (1936). Haematologica, 17, 833.

Reiff, R. H., Nutter, J. Y., Donohue, D. M., and Finch, C. A. (1958). Amer. J. clin. Path., 30, 199.

Ris, H. (1955). In Analysis of Development, p. 91, ed. B. H. Willier, P. A. Weiss, and V. Hamburger. Saunders, Philadelphia.

Suit, H. D. (1957). J. clin. Path., 10, 267.

Woodard, Helen Q., and Holodny, E. (1960). Phys. in med. Biol., 5, 57.

Zilva, Joan F., and Nicholson, J. P. (1960). Clin. Sci., 19, 449. 